PRACE NAUKOWE UNIWERSYTETU EKONOMICZNEGO WE WROCLAWIU

\title{
H.-Christian Brauweiler
}

WHZ Westsächsische Hochschule Zwickau (University of Applied Sciences), Zwickau e-mail: christian.brauweiler@fh-zwickau.de

\section{INTERNAL AUDIT IN A MULTINATIONAL PERSPECTIVE: PROBLEMS AND CHALLENGES ${ }^{1}$}

\section{AUDYT WEWNĘTRZNY W PERSPEKTYWIE MIECDZYNARODOWEJ: PROBLEMY I WYZWANIA}

\author{
DOI: $10.15611 /$ pn.2017.474.02 \\ JEL Classification: M42
}

\begin{abstract}
Summary: The need to standardize procedures and tackle similar questions of auditing, risk management, controlling and similar related topics is vast, especially, but not exclusively in multinational companies. However, smaller companies more and more find themselves in a position to act more globally - or at least internationally - in terms of sourcing as well as sales. This brings new needs for and new foci on topics as Internal Audit as well as Corruption Prevention. This article gives some ideas, hints and challenges towards these topics. In order to clarify the views expressed in this article, the author first gives some general information about internal audit, such as its definition, tasks and objectives, its historical development, legal background, structure and implementation, in order to make clear, on which aspects and understanding the argumentation is based. This introduction will provide a theoretical basis for the description and identification of the potential problems and possible challenges in an international perspective.
\end{abstract}

Keywords: internal audit, SME, multinational cooperation.

Streszczenie: Potrzeba standaryzacji procedur oraz podobne problemy związane m.in. $\mathrm{z}$ audytem, zarządzaniem ryzykiem i controllingiem są bardzo istotne, przede wszystkim w firmach międzynarodowych. Mniejsze firmy muszą jednak coraz częściej działać w sposób bardziej globalny w zakresie pozyskiwania i sprzedaży. Rodzi to potrzebę koncentracji na problemach audytu wewnętrznego i potrzebę zapobiegania korupcji - omawiane w artykule. W celu wyjaśnienia poglądów wyrażonych w opracowaniu autor podaje najpierw ogólne informacje dotyczące audytu wewnętrznego (m.in. jego definicję, zadania oraz cele), aby następnie przedstawić, na jakich aspektach opiera się argumentacja. Ten wstęp zapewnia teoretyczne podstawy do opisu i identyfikacji potencjalnych problemów oraz możliwych wyzwań w perspektywie międzynarodowej.

Slowa kluczowe: audyt międzynarodowy, MŚP, współpraca międzynarodowa.

1 This article is partially based on input in a seminar on IA, conducted at the author's chair during Winter 2016. The author thanks M. Hofmann as well as the group of students for valuable input. The author thanks as well two independent and anonymous reviewers for their comments which after rewriting parts and adding certain information enhanced the quality of the paper. 


\section{Introduction}

Companies have enlarged their international activities in a globalized world considerably. Even SMEs are - depending on the branch of industry - by and large very globalized, thus various management procedures must take this into consideration. Controlling, reporting, external as well as internal auditing face certain new challenges. When we focus on internal auditing in MNC as well as SME, the major problems and challenges in a multinational perspective are bigger and thus more complex processes as well as structures. Furthermore, market conditions tend to change quicker, thus making plans of introducing internal audit void.

This article will initially present general information about internal audit to provide a basic knowledge about its contents and understanding. This is done on a literature-based methodology. Then, its aims and methods will be regarded in order to discuss, if they could be influenced by a multinational perspective.

In a brief survey on the history of internal audit, the author clarifies the potential to adapt to external factors. Finally there will be a depiction about its European, international and especially German legal requirements, conducted as a literature survey. This will show the importance of internal audit for the global economy.

In a second step, the article focusses on the implementation of internal audit within a company to explain its possible structure and processes in practice. The methodology used here is an exploratory one, which takes anonymized examples into consideration. These examples stem from Germany, as the German economy is very export oriented and even SME have a huge proportion of international trade.

Problems and challenges for the successful conduct of the already discussed internal audit's tasks will be evaluated in the third and last part. The main findings will be finally summarized in the conclusion followed by a short statement to the hypothesis which was set up above.

\section{General information}

\subsection{Definition}

There have been various aspects of the term "internal auditing" that changed during the last decades. Thus the definition as well as the contents may be considered dynamic. This derives from changes in business culture, regulations, norms and laws as well as on a natural development of understanding of certain processes, especially with respect to corporate governance. This dynamic character becomes especially clear, when one looks at the IIA's definition which describes "internal auditing" as: "an independent, objective assurance and consulting activity designed to add value and improve an organization's operations. It helps an organization accomplish its objectives by bringing a systematic, disciplined approach to evaluate and improve the effectiveness of risk management, control and governance processes" [IIA 2016a]. 
As various authors, e.g. Lück [2001], Spencer Pickett [2003], and Egner [2011] adopted this definition as well as the circumstance that it was even fully adopted by the German DIIR, the IIA Austria and the SVIR for their definitions, it may be considered as internationally recognised and acknowledged. The following chapters will look closer into the major aspects of this definition.

\subsection{Objectives and tasks}

The aforementioned definition of the IIA clearly states that internal audit thrives to achieve two mayor aims: First, the creation and growth of company value and secondly the optimization of business processes. This should be achieved by operational improvements and the reduction of risk through consulting, assurance activities and supported by a proper risk management. Moreover, regularity and safety shall be determined, as well as accuracy, credibility, appropriateness and economic efficiency. Other objectives of internal audit are the detection of errors and of error causes in order to prevent them in the future [Füss 2005].

The assurance services, which may be considered as traditional tasks, include financial, operational and management auditing.

The financial auditing focuses on the past-oriented assurance of the company's financial and accounting data, such as its balance sheet, profit-and-loss-account or the financial statements of associated companies. Thus, the financial auditing determines the reliability of the information, the regularity of the data, the data gathering and the data presentation to ensure the overall correctness of the accounting and financial system. Furthermore, control mechanisms which are integrated into the process, are checked as well.

The operational auditing is a present and future oriented assurance of the structural and procedural organization of the company. It has its major foundation in comparisons of target and actual figures. It mostly focuses on a system audit to identify the appropriateness and regularity of the company's systems, processes and structures [Hofmann 2005]. Of special attention are the internal information systems, the control systems, the human resources management, the materials management, the production or the IT systems [Lück 2001].

The management auditing - as the name implies - aims at the performance assessment of management and leadership processes with regard to their own set strategy and objectives. Thus it is considerably different in aims and focus from the operational auditing, because it regards the strategic management instead of the operative business processes [Füss 2005]. The objectives are evaluated according to their quality and target conformity, whereas the strategy evaluation focusses more on their logic, professionality and methodology [Hein 2001]. Regarding the content, a special focus is set on the structure and efficiency of the internal risk management system, the assurance of the corporate planning, the efficiency of resource allocation, corporate communication instruments and the technological standard. 
Amling and Bantleon [2007] go beyond listing the aforementioned traditional tasks of auditing. They add as another trait the compliance auditing which partially overlaps with the tasks of the operational and financial audit. Compliance auditing as a whole checks the Corporate Governance, i.e., it is a general regularity assurance of the compliance of internal and statutory rules and thus of the company's compliance system. One major aim is to prevent penalties or law suits. All in all, Knapp points out that requirements and underlying conditions for the financial and management auditing did not significantly change in response to developing tasks, report recipients and responsibilities. However, there was a considerable change in the operational auditing and consulting services [Knapp 2009].

Consulting services contain the assessment and development of solution approaches, which are in many cases tied to the already mentioned assurance activities. These solution approaches consist of a number of recommendations. These recommendations can be subdivided in three categories: They are either already very specific, or they represent a possible approach which still lacks a development of necessary measures ,or they are thirdly just potential solutions whereby it is necessary to draw attention to possible problems. The responsibility for the implementation of these recommendations is carried by the department under scrutiny. Due to its independence, the internal audit has no influence on the resulting decision.

\subsection{Legal requirements}

There are a considerable number of legal requirements in Germany for the implementation of internal audit. The most important requirements are $\S 91$ II of the Stock Corporation Act (AktG), § 64a I of the Insurance Supervision Act (VAG) and $\S 25 \mathrm{a}$ I of the Banking Act (KWG) which force listed corporations, insurance companies and credit institutions to introduce internal audit [Stillfried 2015; Brauweiler 2015a].

As the most important international requirements for internal audit at least the European companies have to look into the 8th Directive of 1984 of the European Union, which did set up a framework for audit committees that are superior to the internal audit. Meanwhile it had been enhanced, altered and finally abolished, thus the Directive 2006/43 EU is relevant. As all Directives have to be introduced into national law of the member state, these Directives as well have been integrated into the German legislation, and 2006/43 EU has been introduced by the German Accounting Law Modernization Act of 2009 (Bil-MoG) which caused an adaption of $\S 107$ of the Stock Corporation Act (AktG) [Peemöller, Kregel 2010]. Most important in this context are the international standards of the IIA which have been adopted by its member, the German DIIR. The IIA-standards provide guidelines with respect to implementing internal audit as well as for criteria regarding the valuation of their quality. Furthermore, quality competencies and features of organizations and people who may implement internal audit are regulated [Bungartz 2016]. 


\section{Implementation of internal audit within a company}

The implementation of internal audit should be considered at any stage or size of a company, however, the level and extent of IA should be adapted to the requirements that are not only constituted by the branch or line of industry, but also by the size. Ultimately necessary is IA in a company, if a workforce of at least 100 people is employed, as then the regular overview could be lost and in terms of adjusted risk management IA has to be installed. Regarding the above-mentioned definition, internal audit supports all business units and the management of a company by auditing and consulting activities. To enable a more efficient and independent implementation, the internal audit should, on the one hand, be organized as a subordinated staff position which has to report directly to the (whole) top management [Füss 2005]. The IIA Practice Advisory Standard 1110-1 even demands that the internal audit should be disciplinary subordinated to the CEO of the department which is responsible for the successful implementation and professionally subordinated to the Audit Committee or the Board of Directors [IIA 2010]. The whole top management, on the other hand, is responsible for the functionality, effectiveness, and documentation of IA, which cannot be delegated to other persons or levels of authority.

The organization of the internal audit as a department depends on external, but also internal factors such as the size and structure of the company or the extent of the task [Hoffmann 1992]. As an example, the staff position of the internal audit should be decentralized, if the company is a multinational enterprise, because of its more complex international structures [Freidank, Pasternak 1992]. The functional structure of the internal audit normally depends on the size of the company, too. If the company or department is of a relatively large size, it is recommended to use specialists for the internal audit, whereas generalists should be used for smaller companies or departments [Füss 2005].

Based on the IIA Standards 2000-2060 and 2200-2600 [IIA 2016b] Freidank and Pasternak [2011] state that the conduct of the internal audit consists of three main steps: planning, implementation and follow up, which may be further subdivided into eight more detailed parts. Due to the already mentioned limited focus of this essay, only the three main steps will be discussed in the following.

The planning process includes the planning of the internal audit programme, the timing and the staff deployment [Buchner 1997] to ensure an effective and efficient resource allocation. All business units and processes should be periodically integrated into the planning process.

In case of the conduct of internal audit, actual and target figures of the underlying assurance objectives are crucially significant [Freidank, Pasternak 2011]. Thus, deviation analysis will be conducted, the origins of the identified deviations, which could be errors or negligent acts or fraudulent intentions, will be figured out in a 
following step [Ossadnik 2009]. The third and last follow up process examines, if the identified deviations could be eliminated to enable the achievement of the operative and strategic corporate targets. The implementation ends with the final assurance of the internal audit itself including the quality and efficiency of its implementation (planning, conduct and follow up). A (partially) external assurance, which must be ordered by the corporate management, is possible [Freidank, Pasternak 2011].

\section{Problems and challenges for IA in a multinational perspective}

According to Lück [2001], the globalization and economic internationalization change the structure and size of companies and the amount of worldwide transactions. These changing global structures as well as the increase in amount of transactions, combined with various intercultural factors, make it necessary to incorporate into internal audit new types of data analytics [Ernst\&Young 2013]. Furthermore, the demand for concise communication structures and processes rises, in order to enable the networking and coordination of global markets [Lück 2001]. The internationalization also strongly intensifies the global price competition [Berwanger, Kullmann 2012] and triggers a societal value change and the emergence of political and social conflicts, both between people as well as industry, based on company size. All these problems have to be addressed by internal audit. Other problematic and challenging impacts are changes within a company such as technological modifications, process and product innovations and the development of decentral and flexible organizations [Füss 2005]. These topics have to be addressed by internal audit, too.

As a result of those fast changing market conditions, significant economic events took place, such as the financial crisis which caused dramatic economic losses, raising unemployment rates and all in all a high demand for more control on a global basis [Strouhal et al. 2012]. Thus, in the 21 st century internal audit got more attention and particularly the demand for more consulting services [Ruud, Bodenmann 2000], not only in big companies, but in SME as well. More effective risk management systems and corporate governance should become a stronger focus of internal audit [Grabmann, Hofer 2014]. According to Ernst\&Young [2013], serious risks are compliance and IT risks, including cyber risks, which do not only affect the banking sector [Brauweiler 2015a]. To prevent new economic crises, international institutions continuously pass and adapt new international standards and guidelines regarding corporate control, such as the already mentioned Directives of the European Union or the Sarbanes-Oxley Act (SOX) which contain higher requirements for internal audit. These new standards are an additional international challenge for internal audit, because they strongly regulate its organization and implementation by law and obligate other companies to fulfil certain internal security and control standards 
[Berwanger, Kullmann 2012]. As an exemplary consequence, security assurances are growing in demand, because liability regulations become more significant which challenges companies to bear more responsibility for their economic activities [Brauweiler 2015b; Füss 2005]. These regulations also account for special due diligence and a higher responsibility for the internal audit in all lines of industry and all sizes of business. Thus, the internal audit should be more future-oriented and focus on the new requirements of the company and the content of its task fulfilment [Lindner 2003].

Furthermore, the internationalization causes several personal challenges for internal auditors such as knowledge about international and national legislative processes and guidelines, political dynamics, foreign mentalities, cultures and different corporate philosophies, dependent on company size and structure. They should furthermore provide personal suitability criteria, such as objectivity, flexibility and advanced language skills [Lück 2000]. Thus, another challenge of the internationalization is to find, train and manage qualified staff which is also willing for being sent out from their headquarters to work abroad.

It may be concluded that the internationalization causes a fast changing business environment which is linked to several corresponding problems for the economy and hence the internal audit. Companies need to accelerate their own change, while the internal audit is challenged to integrate into this process and to adapt to the actual environmental requirements [Ernst\&Young 2013].

\section{Conclusions}

Internal audit is, internationally defined by the IIA, an independent and objective assurance and consulting service which is directly subordinated to the corporate management, aiming at the improvement of the company's processes and the additional creation of value. Due to its increasing importance, which may be explained by the appearance of various economic scandals, the national and international legislation has passed and adapted different laws and standards to raise the requirements for its implementation and structure. Due to its definition and historical development the internal audit may be characterised as highly dynamic which is necessary for its further adaptation to changing internal and external factors which cause different economic requirements.

One of these external factors is the ongoing internationalization which also includes all companies, independent of size and structure. As a result, the internal audit faces different problems and challenges regarding its successful implementation, such as an increase in the company's size, the amount of international transactions, internal communication networks, legal requirements for internal audit, the demand for risk management systems, corporate governance, consulting services and qualified staff. Other resulting challenges are changes in organizational structures and technologies. 


\section{References}

Amling T., Bantleon U., 2007, Handbuch der Internen Revision, Erich Schmidt, Berlin.

Berwanger J., Kullmann S., 2012, Interne Revision, Gabler, Wiesbaden.

Brauweiler C., 2015a, Risikomanagement in Banken und Kreditinstituten, Springer, Berlin

Brauweiler C., 2015b, Risikomanagement in Unternehmen, Springer, Berlin.

Buchner R., 1997, Wirtschaftliches Prüfungswesen, Vahlen, München.

Bungartz O., 2016, Internationale Standards für die berufliche Praxis der Internen Revision, http:// www.internerevisiondigital.de/ce/internationale-standards-fuer-die-berufliche-praxis-derinternen-revision/detail.html.

Egner T., 2011, Grundlagen der internen Revision, [in:] Freidank C. Peemöller V. (eds.), Kompendium der Internen Revision, Erich Schmidt, Berlin.

Ernst\&Young, 2013, Challenges of the global internal audit function, http://www.ey.com/Publication/ vwLUAssets/ViewPoints:_Challenges_of_global_internal_audit/\%24FILE/ACLS_ViewPointsChallenges_of_global_internal_audit_May\%202013_AU1630.pdf.

Freidank C., Pasternak N., 2011, Theoretische Fundierung der Internen Revision, [in:] Freidank C., Peemöller V. (eds.), Kompendium der Internen Revision, Erich Schmidt, Berlin.

Füss R., 2005, Die Interne Revision, Erich Schmidt, Berlin.

Grabmann E. Hofer D. 2014, Impact Factor on the Development of Internal Auditing in the 21st Century, ACRN Journal of Finance and Risk Perspectives, vol. 3, no. 3, p. 67-80.

Hein G., 2001, Management auditing, [in:] Lück W. (ed.), Lexikon der internen Revision, Oldenbourg, München 2001.

Hoffmann F., 1992, Interne Revision, [in:] Coenenberg A., Wysocki K. (eds.), Handwörterbuch der Revision, Poeschel, Stuttgart.

Hofmann R., 2005, Prüfungs-Handbuch, Erich Schmidt, Berlin.

IIA, 2010, Practice Advisories, The Institute of Internal Auditors, http://www.theiia.org/bookstore/ downloads/freetomembers/0_2032.dl_pas.pdf.

IIA, 2016a, Definition of internal auditing, Chartered Institute of Internal Auditors, https://www.iia.org. $\mathrm{uk} /$ resources/global-guidance/definition-of-internal-auditing.

IIA, 2016b, International Standards for the Professional Practice of Internal Auditing, The Institute of Internal Auditors,http://www.theiia.org/guidance/standards-and-guidance/ippf/standards/full-standards/?search=risk.

Knapp E. 2009, Interne Revision und Corporate Governance, Erich Schmidt Berlin.

Lindner M., 2003, Interne Revision, [in:] Jahns C., Heim G. (eds.), Handbuch Management, SchäfferPoeschel, Stuttgart.

Lück W., 2000, Die Zukunft der Internen Revision, Erich Schmidt, Berlin.

Lück W., 2001, Lexikon der internen Revision, Oldenbourg, München.

Ossadnik W., 2009, Controlling Oldenbourg, München.

Peemöller V., Kregel J., 2010, Grundlagen der Internen Revision, Erich Schmidt, Berlin.

Ruud F., Bodenmann J.M., 2000, Entwicklungen in der Internen Revision: Interesante Umfrageergebnisse zur Zukunft der Internen Revision, Der Schweizer Treuhänder, vol. 10, p. 1029-1036.

Spencer Pickett K., 2003,The Internal Auditing Handbook, Wiley, London.

Stillfried N., 2015, Die bedrohte Unabhängigkeit Interner Revisoren in Deutschland, https://www. transparency.de/fileadmin/pdfs/Themen/Wirtschaft/Die_Unabhaengikeit_Interner_Revisoren_in_ Deutschland_ausfuehrliche_Ergebnisse_CD.pdf.

Strouhal J., Bonaci C., Mustata R., 2012, Corporate Governance and financial crisis, International Advances in Economic Research, vol. 18, no. 1, p. 122-123. 